\title{
First record of the peacock fly Callopistromyia annulipes (Diptera: Ulidiidae) in Romania
}

\author{
Alexandru-Mihai Pintilioaie ${ }^{1}$, Cosmin-Ovidiu Manci ${ }^{2}$ \\ 1 Research Group in Invertebrate Diversity and Phylogenetics, Faculty of Biology, "Alexandru Ioan \\ Cuza" University of Iaşi, Romania \\ 2 S.E.O.P.M.M. Oceanic-Club, Constanţa, Romania \\ Corresponding author: Alexandru-Mihai Pintilioaie (alexandrupintilioaie@gmail.com)
}

Received 7 February 2020 | Accepted 17 March 2020 | Published 30 June 2020

Citation: Pintilioaie A-M, Manci C-O (2020) First record of the peacock fly Callopistromyia annulipes (Diptera: Ulidiidae) in Romania. Travaux du Muséum National d’Histoire Naturelle “Grigore Antipa” 63(1): 87-91. https:// doi.org/10.3897/travaux.63.e50920

\begin{abstract}
The peacock fly Callopistromyia annulipes (Macquart, 1855) is recorded for the first time in Romania, from several locations. Its current distribution in Europe and some data regarding the ecology of the species are presented.
\end{abstract}

\section{Keywords}

Allochthonous species, Brachycera, distribution, Europe, picture-winged flies.

The family Ulidiidae (Diptera: Tephritoidea), known as picture-winged flies, comprises small sized species, usually with different patterns of spots or stripes on their wings and bodies. Approximately 110 species are known in Europe (Kameneva 2008).

The peacock fly Callopistromyia annulipes (Macquart, 1855) (Fig. 1) is a Nearctic species, originally described in the genus Platystoma Meigen, 1803. The genus Callopistromyia Handel, 1907 is represented by two species, C. annulipes and C. strigula (Loew, 1873) both described from the Nearctic Region and widespread in the United States and southern Canada (Kameneva and Korneyev 2006). The vernacular English name refers to its habits of displaying the spotted wings raised vertically and pointed forward (Fig. 2), which resembles to a peacock tail. 


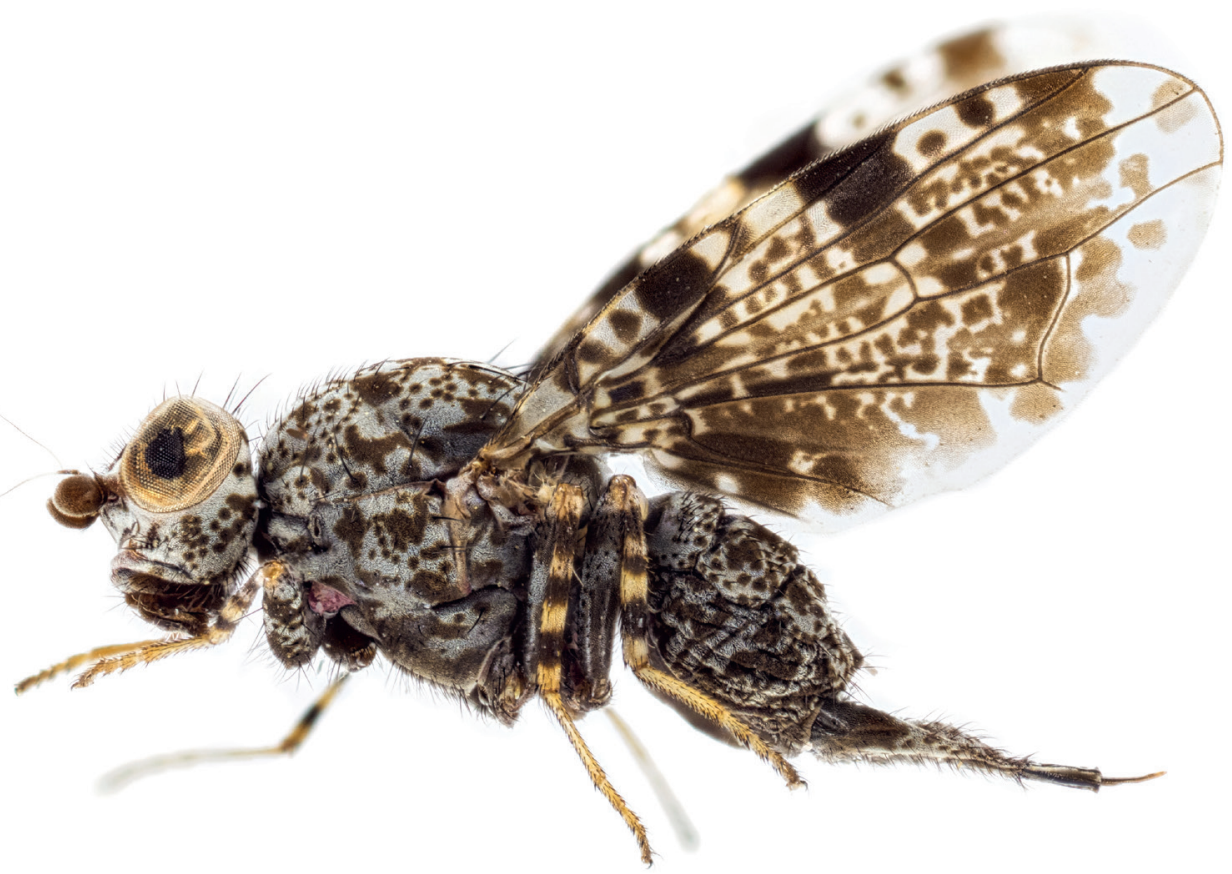

Figure 1. Female of Callopistromyia annulipes, lateral view.

Its first occurrence in the Palearctic Region came from Southern Switzerland in 2007, when one female was found in a vineyard (Merz 2007). It was recorded in the same year from Germany (Merzand Van Gyseghem 2007) and in 2011 from Netherlands (Smith and Hamers 2011). After this, it is recorded from Italy (flies photographed and posted on Diptera.info website by Niolu P. in 2009 and by Galliani C. in 2010), France (from a picture posted on Diptera.info website, in 2011), Slovenia (from an observation uploaded by Weites M. on Observation. org database, in 2011), Austria and Slovakia (female specimens collected in 2014 with beer traps) (Korneyev et al. 2014). In 2016, the species was found in Hungary (Kameneva and Pekarsky 2016) and in 2017 in Belgium (Ravoet and Farinelle 2017) and Czech Republic (Dvořák 2017). The last published records of the species in a new country in Europe are from Poland (Klasa and Jałoszyński 2018) and Ukraine (Dvořák et al. 2019).

Given the known European distribution of Callopistromyia annulipes, the species was expected to be found also in Romania (Fig. 3). We examined 22 specimens, as follows: 1 specimen (not collected), Timiș county, Surducu Mic (near), 11.08.2018, $45.7581^{\circ} \mathrm{N} / 22.1089^{\circ} \mathrm{E}$, observed by Ionela Slejiuc; 1 \% , Romania, Arad county, Conop (near), $11.10 .2018,46.0972^{\circ} \mathrm{N} / 21.8816^{\circ} \mathrm{E}$, leg. Pintilioaie Alexandru; 1 , Romania, Arad county, Milova (near), $14.10 .2018,46.0877^{\circ} \mathrm{N} / 21.8068^{\circ} \mathrm{E}$, Leg. Pintilioaie Alexandru; 1 \& (not collected), Romania, Galați county, Hanu Conachi 


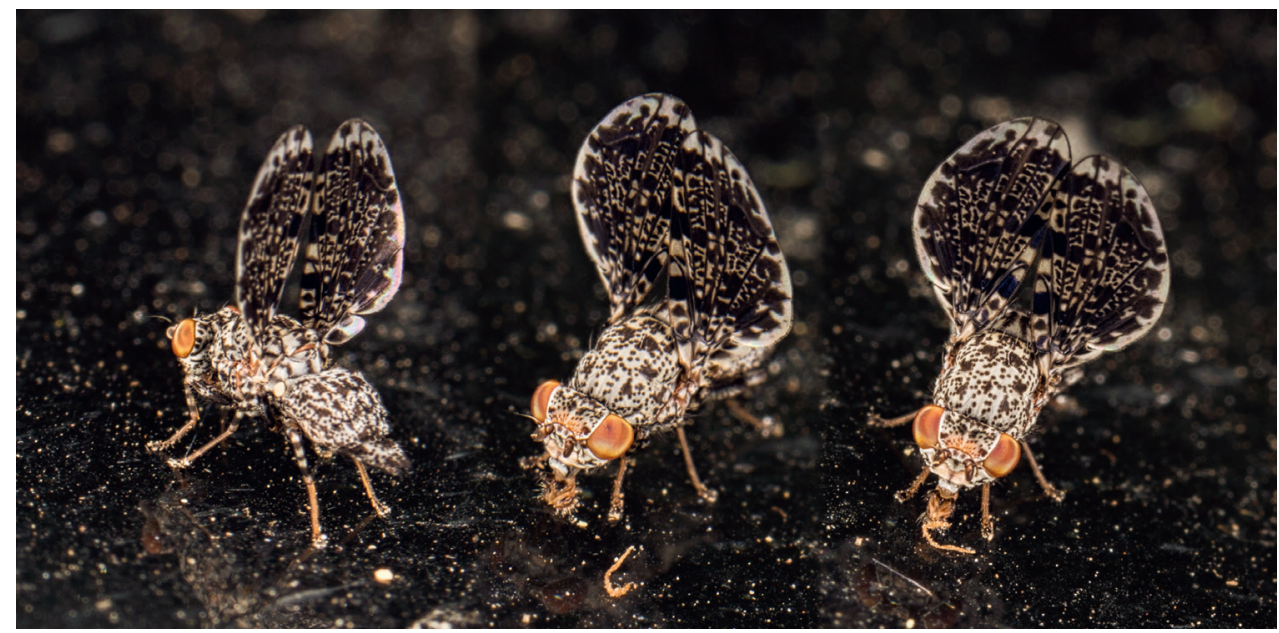

Figure 2. Female of Callopistromyia annulipes, in situ, showing its peculiar wings displaying.

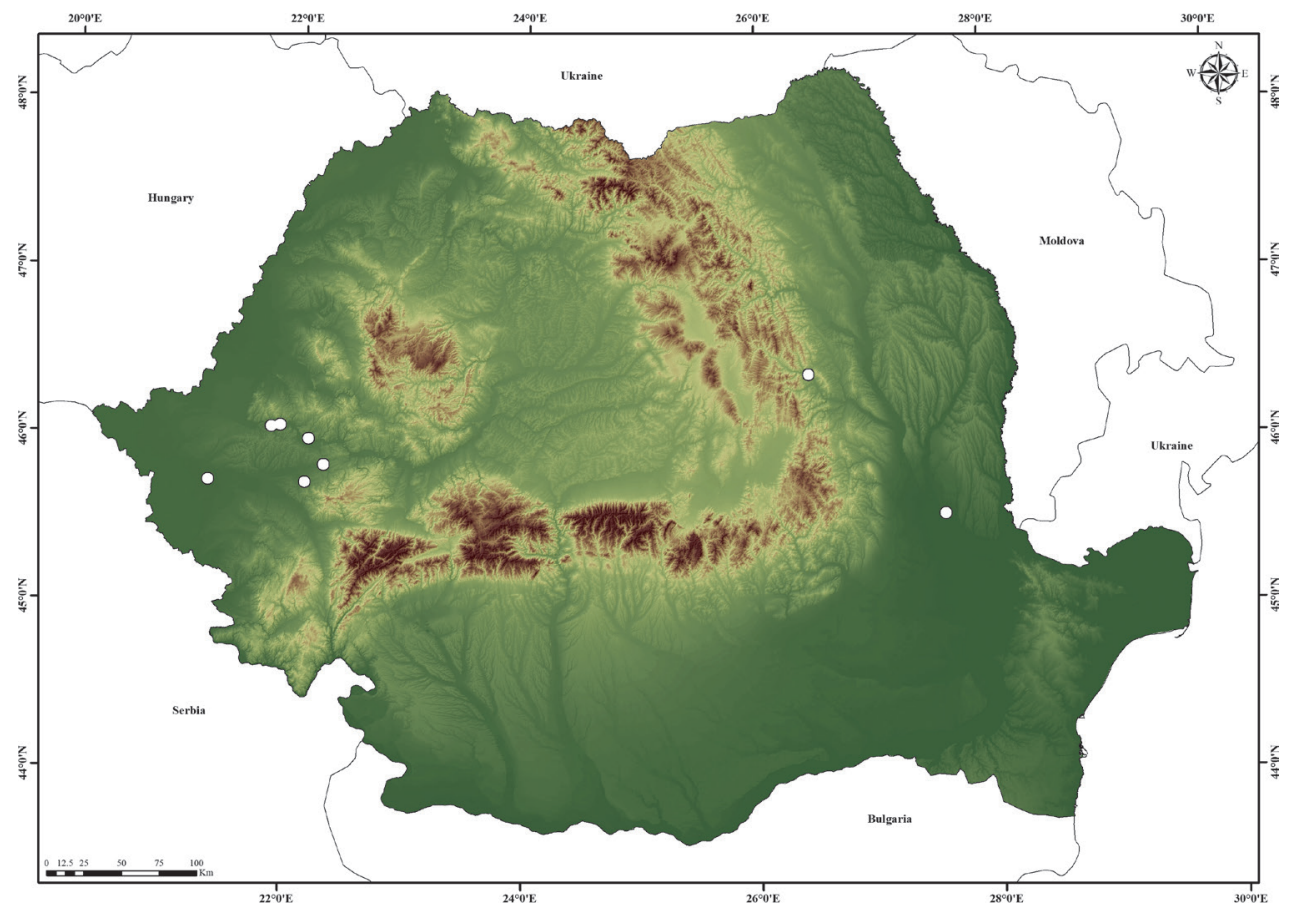

Figure 3. The distribution of Callopistromyia annulipes in Romania.

(near), in a Robinia forest on the car, $19.06 .2019,45.5817^{\circ} \mathrm{N} / 27.5950^{\circ} \mathrm{E}$, observed by Cosmin Manci; 1 (not collected), Romania, Arad county, Vărădia de Mureș 
(near), $16.08 .2019,46.0187^{\circ} \mathrm{N} / 22.1295^{\circ}$, observed by Pintilioaie Alexandru; 1 , Romania, Bacău county, Comănești (near), 1-24.08.2019, 46.4267 ${ }^{\circ} \mathrm{N} / 26.4427^{\circ} \mathrm{E}$, wine trap, leg. Pintilioaie Alexandru; 5, 7 $\lambda$, Romania, Bacău county, Comănești (near), $1-24.08 .2019,46.4267^{\circ} \mathrm{N} / 26.4427^{\circ} \mathrm{E}$, beer trap, leg. Pintilioaie Alexandru; 1 ㅇ, Romania, Bacău county, Comănești (near), 9.09.2019, $46.4267^{\circ} \mathrm{N} / 26.4427^{\circ} \mathrm{E}$, on Robinia logs, leg. Pintilioaie Alexandru; 1 specimen (not collected), Romania, Timiș county, Timișoara (near), $10.09 .2019,45.7546^{\circ} \mathrm{N} / 21.2795^{\circ} \mathrm{E}$, observed by Danka Dragomir; 1 specimen (not collected), Romania, Timiș county, Zorani (near), 24.09.2019, $45.8674^{\circ} \mathrm{N} / 22.2637^{\circ} \mathrm{E}$, observed by Pintilioaie Alexandru; 1 q, Romania, Bacău county, Comănești (near), $11.10 .2019,46.4267^{\circ} \mathrm{N} / 26.4427^{\circ} \mathrm{E}$, on Robinia logs, leg. Pintilioaie Alexandru. The collected specimens are deposited in the collection of "Grigore Antipa" National Museum of Natural History, Bucharest, Romania.

Regarding the ecology of the species, the adults are found usually at exposed places, on cars (Steyskal 1979; Kameneva and Pekarsky 2016; this study), trash cans and soil (Kameneva and Pekarsky 2016), on flag poles, handrails, curbstones (Dvořák et al. 2017) and also on different deciduous dead trees, like Populus deltoides (Steyskal 1979), Populus alba (Klasa and Jałoszyński 2018), Robinia pseudoacacia (Rolke 2017; this study), Fagus sp. (Korneyev et al. 2014). They were observed feeding on frass of wood-boring beetles in live trees of Robinia pseudoacacia (Steyskal 1979) and are also attracted to beer traps (Korneyev et al. 2014; Dvoŕák 2017; Dvorák et al. 2019; this study) and in a much lower number, to wine traps (this study). The females were observed ovipositing on dead trees of Robinia pseudoacacia and puparia were found in decaying cambium of Acer negundo (Steyskal 1979).

Increasing the sampling effort (especially using beer traps) throughout the country will certainly reveal that Callopistromyia annulipes is much more widespread in Romania.

\section{Acknowledgments}

We express our gratitude to Călin Hodor from Wildlife Management Consulting and Petrișor Galan from Biodiversity Research and Consulting for helping with some of the fieldwork expeditions in which we have found some of the specimens, and also to Danka Dragomir and Ionela Slejiuc for sending us distribution points for the species. We are also thankful to Alina Cîşlariu and Dragoș Ștefan Măntoiu for helping with generation of the distribution map.

\section{References}

Dvořák L (2017) The first records of Callopistromyia annulipes (Macquart, 1855) (Diptera: Ulidiidae) from the Czech Republic. Acta Musei Silesiae Scientiae Naturales 66: 111112. https://doi.org/10.1515/cszma-2017-0012. 
Dvorak L, Čejka T, Semebauer M (2017) New records of Callopistromyia annulipes (Diptera: Ulidiidae) from Slovakia. Folia Oecologica 9(2): 18-21.

Dvořák L, Haenni JP, Dvořáková K, Kameneva EP, Mariychuk R, Manko P, Oboňa J, Korneyev VA (2019) Some insects from beer traps in westernmost Ukraine. Українська ентомофауністик 10(2): 1-6. http://dx.doi.org/10.5281/zenodo.3584947.

Kameneva EP (2008) New and little-known Ulidiidae (Diptera, Tephritoidea) from Europe. Vestnik zoologii 42(5): 427-454.https://doi.org/10.2478/v10058-008-0010-6.

Kameneva EP, Korneyev V (2006) Myennidini, a new tribe of the subfamily Otitinae (Diptera: Ulidiidae), with discussion of the suprageneric classification of the family. Israel Journal of Entomology 35-36: 497-586.

Kameneva EP, Pekarsky O (2016) First Record of Nearctic invader, the peacock fly Callopistromyia annulipes Macquart (Diptera: Ulidiidae: Otitinae: Myennidini) from Hungary. Ukrainska Entomofaunistyka 7(4): 38.

Klasa A, Jałoszyński P (2018) First record of the peacock fly Callopistromyia annulipes (Macquart, 1855) (Diptera: Ulidiidae) in Poland. Bulletin of the Dipterological Section of the Polish Entomological Society 34: 22-29. DOI: 10.5281/zenodo.149521.

Korneyev VA, Dvořák L, Kameneva EP (2014) New Records of Callopistromyia annulipes Macquart (Diptera: Ulidiidae: Otitinae: Myennidini) in Europe. Ukrainska Entomofaunistyka 5(2): 10.

Meigen JW (1803) Versuch einer neuen Gattungs Eintheilung der europäischen zweiflügligen Insekten [Attempt to classify the European two-winged insects]. Magazin für Insektenkunde 2: 259-281. [in German]

Merz B (2007) Callopistromyia annulipes (Macquart, 1855), a Nearctic species of Ulidiidae (Diptera), new for the Palaearctic Region. Studia dipterologica 14(1): 161-165.

Merz B, Van Gyseghem R (2007) Callopistromyia annulipes (Macquart, 1855), neu auch für Deutschland (Diptera, Ulidiidae) [Callopistromyia annulipes (Macquart, 1855), new also for Germany]. Studia dipterologica 14(1): 165-166. [in German]

Ravoet J, Farinelle C (2017) The peacock fly Callopistromyia annulipes (Macquart, 1855): a long expected new addition to the Belgian fauna (Diptera: Ulidiidae). Bulletin de la Société royale belge d'Entomologie 153: 121-122.

Rolke D (2017) Die invasive Pfauenfliege Callopistromyia annulipes (Macquart, 1855) (Diptera, Ulidiidae) - neu für die Fauna Brandenburgs [The invasive peacock fly Callopistromyia annulipes (Macquart, 1855) (Diptera, Ulidiidae) - new for the fauna of Brandenburg]. Märkische Entomologische Nachrichten 19(1): 109-111. [in German]

Smit JT, Hamers B (2011) De invasieve Noord-Amerikaanse pauwvlieg Callopistromyia annulipes nieuw voor Nederland (Diptera: Ulidiidae) [The invasive North American peacock fly Callopistromyia annulipes new to the Netherlands (Diptera: Ulidiidae)]. Nederlandse Faunistische Mededelingen 36: 23-27. [in Dutch]

Steyskal GC (1979) Biological, anatomical, and distributional notes on the genus Callopistromyia Hendel (Diptera: Otitidae). Proceedings of the Entomological Society of Washington 81(3): 450-455. 